\title{
Niezłomny wśród swoich i obcych, wyrozumiały wobec kraju. Postawa Stanisława Gliwy jako emigranta
}

\author{
JoAnna HaeaczKiewicz
}

ORCID: o०oo-oooI-7143-789x

(Uniwersytet Jagielloński w Krakowie)

\section{STYL BYCIA EMIGRANTEM}

Za emigracją niemal zawsze stoi jakiś przymus - na przykład polityczny, ekonomiczny czy społeczny. Tego, kto w warunkach pokoju opuszcza swoją ojczyznę i czyni to dobrowolnie, bez wyraźnego powodu, nie doświadczywszy żadnej opresji, określa się raczej jako kosmopolitę albo - zwłaszcza współcześnie, w dobie pracy zdalnej - cyfrowego nomadę. Taka osoba nie rozpatruje wyjazdu jako straty czy czegoś negatywnego, przeciwnie - w ten sposób realizuje swoją wolność. Co innego emigrant. Ten jest podwójnie wyalienowany. Emigrując, traci bezpośredni kontakt z pierwotną wspólnotą i staje przed obcymi drzwiami z prośbą o gościnę, która dopiero po czasie może przekształcić się w zadomowienie. Emigrantem jest się tak długo, jak długo doświadcza się izolacji od otoczenia - zarówno nowego, jak i porzuconego. Wydaje się zatem, że czymś naturalnym, a nawet koniecznym jest dążenie do wyjścia z tego niepożądanego stanu - czy to przez asymilację, czy to przez powrót.

Historia tymczasem pokazuje, że niektórzy zamiast obrać jeden ze wskazanych kierunków, ze statusu emigranta uczynili jeśli nie styl życia, to przynajmniej istotny składnik własnej tożsamości. Andrzej Stanisław Kowalczyk, pisząc o polskim wychodźstwie powrześniowym, nazwał tych ludzi emigrantami uporczywymi ${ }^{\mathrm{T}}$. Przyjęta przez nich strategia polegała na umiejętnym układaniu się z izolacją - tak, 
by jednocześnie dochować wierności swoim politycznym ideałom i nie dać się „zdegradować do statusu pariasa w obcym społeczeństwie”². Część z tych osób określa się niezłomnymi.

Do grona permanentnych wychodźców, którzy swoją biografią wypełnili etos tak zwanej Drugiej Wielkiej Emigracji, można też zaliczyć bohatera tego szkicu - Stanisława Gliwę. Ten dziś szerzej nieznany artysta książki, właściciel jednoosobowego warsztatu drukarskiego, był jednym z najważniejszych grafików emigracji niepodległościowej. Jako żołnierz, przemierzając szlak armii Andersa, nie tylko walczył, ale i tworzył szaty graficzne książek, spośród których największy sukces odniosła trzytomowa Bitwa o Monte Cassino Melchiora Wańkowicza ${ }^{3}$ - reportaż, w którym tekst nierozerwalnie łączy się z warstwą wizualną. Gliwa we Włoszech był aktywnym współpracownikiem Oddziału Kultury i Prasy 2. Korpusu - prężnego referatu odpowiadającego za politykę kulturalną w szeregach armii. Artysta projektował dla niego okładki i layouty publikacji, odpowiadał też za kontakty z drukarniami. Aby dokończyć rozpoczęte projekty wydawnicze, został w Italii nawet wtedy, gdy na mocy decyzji aliantów dowództwo i żołnierze armii znajdowali się już w Wielkiej Brytanii.

Gliwa, podobnie jak tysiące ocalałych z pożogi wojennej andersowców, trafił w 1947 roku do zorganizowanych na Wyspach obozów dla żołnierzy, skąd mógł wyjechać $\mathrm{z}$ powrotem do Polski lub dalej emigrować. Przeczuwając represje, jakie mogłyby go spotkać w rządzonym przez komunistów kraju, z niechęcią i bez konkretnej wizji przyszłości zgodził się na emigrację. Po namyśle, jako jeden z tak zwanych opornych, wstąpił do Polskiego Korpusu Przysposobienia i Rozmieszczenia (ang. Polish Resettlement Corps), organizacji zajmującej się przygotowaniem kombatantów do życia w obcym społeczeństwie. Ta decyzja zaważyła na jego całym późniejszym życiu. Internowany we wrześniu I939 roku w Łucku przez żołnierzy sowieckich, a następnie wywieziony do obozów, z których wyszedł na mocy układu Sikorski-Majski, Gliwa po wojnie już nigdy nie odwiedził rodzinnych stron - Rzeszowszczyzny i Krakowa - w czym okazał się bardziej konsekwentny od niejednego głośnego działacza na emigracyjnym świeczniku. Nie doczekawszy przemian wolnościowych, zmarł w Londynie w 1986 roku.

Takie uporczywe trwanie w izolacji cechowało jedynie nielicznych. Emigracja powrześniowa w swojej masie była zróżnicowana. Po 1957 roku wielu wychodźców, zwłaszcza tych anonimowych, ale nie tylko, uzyskawszy paszport konsularny PRL-u, odwiedzało swoje rodziny w kraju oraz spędzało tam urlopy, wbrew dominującej

2 Ibidem, s. 187.

3 M. Wańkowicz, Bitwa o Monte Cassino, t. 1-3, oprac. graf. S. Gliwa, L. Haar, Z. Haar, Rzym-Mediolan 1945-1947. 
na emigracji opinii, że bywanie w Polsce Ludowej jest, delikatnie mówiąc, niebezpieczne i niestosowne $e^{4}$ Typograf nie pokusił się o skorzystanie z tej możliwości, co nie oznacza, że nie utrzymywał kontaktów z krajem. Przeciwnie - jego sieć znajomości $\mathrm{z}$ rodakami była rozbudowana i $\mathrm{z}$ biegiem lat, $\mathrm{w}$ miarę luzowania polityki izolacji, tylko się powiększała.

Grafik jeszcze przed śmiercią zdecydował się przesłać część swojego dorobku, głównie w postaci druków, do Muzeum Sztuki Książki we Wrocławiu (obecnie Dział Sztuki Wydawniczej Muzeum Narodowego). Maria Gliwa w latach dziewięćdziesiątych przekazała $z$ kolei trzon mężowskiej spuścizny nie instytucjom emigracyjnym czy obcym, lecz Wojewódzkiej Bibliotece Publicznej - Książnicy Kopernikańskiej w Toruniu. Zwłaszcza materiały przechowywane w Toruniu, a wśród nich bogaty zbiór korespondencji, poświadczają istnienie rozlicznych kontaktów typografa $\mathrm{z}$ rodakami w kraju. Różnorodne i długotrwałe, dopełniają obrazu Gliwy jako uporczywego emigranta - człowieka żyjącego w kilku środowiskach, ale nigdzie niezakorzenionego. Dziś, mając na wyciągnięcie ręki wszelkie źródła umożliwiające poznanie biografii zasłużonego grafika, warto odpowiedzieć na pytanie, jaki styl bycia emigrantem sobie wypracował - szczególnie w kontekście relacji z negowanym przez część wychodźców PRL-em.

\section{NIEZłoMNY wśRóD SWOICH I OBCYCH}

Z wojny Stanisław Gliwa wyszedł jako żołnierz broni pancernej w stopniu kapra1a. Wyjąwszy krótki epizod z września I939 roku, przez cały ten czas służył w armii generała Andersa, zorganizowanej na Wschodzie z byłych więźniów obozów sowieckich. Doświadczenie obozowe oraz służba w szeregach tej formacji uczyniły z Gliwy zagorzałego przeciwnika Związku Radzieckiego. W tym kontekście decyzja o pozostaniu za granicą stała się oczywista. „Do kraju wracać nie mogę, bo pracowałem w propagandzie, a gdybym nawet nie pracował, to i tak nie wróciłbym - byłem już raz u tych Azjatów, poznałem ich na wylot i w «polskiej republice sowieckiej» żyć nie zamierzam" - pisał z Rzymu do Stanisława Szukalskiego 5 .

Lata 1947-I986 wypełniła mu intensywna praca na rzecz polskiej społeczności w Londynie. Artysta, co znamienne, zainaugurował ją opracowaniem graficznym

4 Dwie skrajne postawy emigracyjne - realistów i niezłomnych - na barwną paletę odcieni interesująco rozbił Paweł Chojnacki. Zob. idem, Realizm nieztomnych. Lokalne środowiska emigracyjne wobec komunizmu i rzeczywistości krajowej od lat pięćdziesiatych po siedemdziesiąte, w: Londyn - stolica Polski. Emigracja polska 1940-1990, Warszawa 2014, s. 100-127.

5 Archiwum Emigracji w Toruniu (dalej: AE), kolekcja S. Szukalskiego, list S. Gliwy do S. Szukalskiego z 26 II 1947 r., sygn. AE/SS/XXXII/5. 
map do tomu wspomnień Władysława Andersa Bez ostatniego rozdziatu ${ }^{6}$. Później dorywczo współpracował z wieloma polskimi wydawcami, między innymi Gryfem, Veritasem, sekcjami wydawniczymi polskiej YMCA i Stowarzyszenia Polskich Kombatantów czy też z Polską Fundacją Kulturalną. Jego grafiki - a specjalizował się w linorycie i drzeworycie - zdobiły wydania polonijnych dzienników i tygodników, dla których tworzył winiety oraz całe szaty graficzne. Nie mogąc utrzymać się jako freelancer ani znaleźć zatrudnienia w lokalnych art studiach, przystał wreszcie na posadę instruktora terapii zajęciowej w polskim szpitalu dla neurotyków w Mabledon Park, nieopodal Royal Tunbridge Wells. Tam w ręcznej zecerni i drukarni, zorganizowanej przez Anatola Krakowieckiego, pomagał pacjentom rozładować napięcia wywołane chorobą. W chwilach wolnych od pracy składał i drukował swoje pierwsze książki opatrzone własnym gmerkiem, lecz wydane cudzym nakładem - między innymi Społeczności Akademickiej Uniwersytetu Stefana Batorego w Wilnie7. Na krótko związał się też z Czesławem i Krystyną Bednarczykami, założycielami Oficyny Poetów i Malarzy. W Mabledonie typograf pracował do 1957 roku, następnie przeniósł się do drukarni Catholic Times i Rollprint.

Artysta, sam daleki od politykowania, obracał się w Londynie od początku w kręgach osób o jasno sprecyzowanych poglądach na sprawę polską, reprezentujących stanowisko legalizmu. To zapewne ich wpływ - na równi z przeżyciami obozowymi - skłonił Gliwę do pozostania za granicą i ugruntował w nim przekonanie, że władza w kraju została narzucona przez zewnętrzne mocarstwo. Z listów wiadomo, że grafik cenił postawę generała Kazimierza Sosnkowskiego ${ }^{8}$, legalisty zmierzającego do pogodzenia zwaśnionych stronnictw, gardził natomiast emigracyjnymi niesnaskami, w których dopatrywał się jedynie koniunkturalizmu. Był przekonany, że przedstawiciele rządu na uchodźstwie roztrwonili swój potencjał polityczny, lecz nie widział dla nich alternatywy i dlatego, wierny sobie, wytrwale mieszkał w obcym i, trzeba dodać, nielubianym przez siebie kraju:

\section{\D Dużo moich przyjaciół porozjeżdżało się po całym świecie. [...] Wszyscy mi raczej doradzają przyjazd i pomoc w stawianiu pierwszych kroków. Jednak ja, dopóki będę mógł wytrzymać, będę tu siedział, bo mimo wszystko, choć Anglików nienawidzę, to muszę przyznać, że równocześnie naród ten mi imponuje. Jest to kraj na pewno najbardziej}

6 W. Anders, Bez ostatniego rozdziatu. Wspomnienia z lat 1939-1946, Newtown 1949.

7 Były to: tomik poezji Bronisława Przyłuskiego Strofy o malarstwie (1953), teka rysunków Mariana Bohusza-Szyszki (1953) oraz Ofiara Stefanii Zahorskiej (1955).

8 AE, kolekcja S. Szukalskiego, list S. Gliwy do S. Szukalskiego z 16 II 1948 r., s. 3, sygn. AE/SS/ $\mathrm{XXXII/5.}$ 
zbliżony do Europy, w której ja się urodziłem i do której chciałbym bardzo kiedyś wrócić9.

- pisał o swoich korzeniach w 1949 roku do Stanisława Szukalskiego, artysty niemal opętanego obsesją polskości, ale praktycznie od dzieciństwa zadomowionego w Stanach Zjednoczonych.

Stanisław Gliwa w polskim Londynie dość szybko zyskał status autorytetu w dziedzinie sztuk plastycznych i użytkowych. Był jurorem konkursów, jak również sam otrzymywał nagrody, projektował sztandary, dyplomy, sygnety, zaproszenia na polonijne wydarzenia oraz publikacje rocznicowe. Choć zarzekał się, że nie potrafi pisać, przesyłał swoje opinie do prasy ${ }^{\mathrm{IO}}$, był w niej także często opisywany. Jako artysta słynął z zamiłowania do szlachetnych materiałów i klasycznego piękna tradycyjnej, przedindustrialnej typografii. Styl jego grafik nawiązywał też do osiągnięć polskiej plastyki międzywojennej, stąd być może - na zasadzie sentymentu jego popularność na emigracji. Mimo tych wszystkich osiągnięć działalność na swój rachunek rozpoczął późno, bo dopiero w 1963 roku, mając pięćdziesiąt trzy lata. Wcześniej nie pozwoliły mu na to niepewne warunki materialne oraz częste przeprowadzki. Wielu byłych żołnierzy Polskich Sił Zbrojnych, którzy zdecydowali się zostać na Wyspach, od początku utrzymywało się z drobnego rzemiosła uprawianego we własnych warsztatach na potrzeby polskich odbiorców. Podobny cel, oczywiście wsparty ambicjami artystycznymi, przyświecał Gliwie. Nowy etap w życiu zainaugurował pracą Samuel Tyszkiewicz. Artysta-typograf ${ }^{\mathrm{II}}$, będącą jednocześnie hołdem złożonym zmarłemu we Włoszech drukarzowi oraz manifestem własnych poglądów na sztukę książki. W następnych latach typograf wydrukował w bibliofilskich nakładach prawie czterdzieści tytułów - były to głównie tomiki poetyckie polskich autorów, w całości finansowane przez twórców.

Równocześnie na początku lat sześćdziesiątych Gliwa stopniowo otworzył się na świat anglojęzyczny i odnalazł w nim swoich pobratymców, którzy podobnie jak on parali się tworzeniem książek w duchu Arts and Crafts. Wcześniej uniemożliwiała mu to słaba znajomość języka, którego długo nie mógł dobrze przyswoić, zajęty walką o ekonomiczny byt w polskojęzycznym getcie. Oficyna Stanisława Gliwy, mimo że powstała w odpowiedzi na specyficzne wymagania emigracyjnego rynku książki, na równych prawach dołączyła do ruchu prywatnych oficyn (ang. private press movement) i z miejsca stała się jedną z jego najznamienitszych przed-

9 AE, kolekcja S. Szukalskiego, list S. Gliwy do S. Szukalskiego z 27 I 1949 r., sygn. AE/SS/XXXII/5.

10 Stanisław Gliwa był autorem kilkunastu krótkich polemicznych artykułów i listów poświęconych sztuce, zamieszczanych głównie w „Tygodniu Polskim” i „Wiadomościach”.

11 B. Przyłuski et al., Samuel Tyszkiewicz. Artysta-typograf, oprac. typograf. S. Gliwa, Southend-on-Sea 1962. 
stawicielek. Gliwa jako jedyny obcokrajowiec należał do stowarzyszenia London Chappel of Private Press Printers, któremu honorowo prezesowała Beatrice Warde, wpływowa teoretyczka typografii, autorka słynnego eseju o typografii funkcjonalnej ${ }^{\text {I2 }}$. Dużym wyróżnieniem dla Polaka, niemalże aktem przysposobienia, było zaproszenie go w 1976 roku do wystawy zorganizowanej z okazji... pięćsetlecia drukarstwa

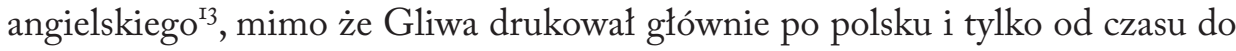
czasu przyjmował zlecenia w obcych językach. Nie była to rzecz jasna jedyna zbiorowa wystawa, w której wziął udział, korzystając z przynależności do grupy niszowych twórców. O jego pracowni pisały też specjalistyczne periodyki anglojęzyczne oraz osoby z kręgu private presses ${ }^{\mathrm{I}}$. Zyskana w ten sposób popularność zaowocowała nowymi klientami oficyny oraz pozwoliła mu sprzedawać piękne druki na obcym rynku kolekcjonerów, co nie umknęło uwadze krytyki emigracyjnej, która pokpiwała, że Gliwa w kunsztownej oprawie graficznej zamyka słabe literacko teksty, ale dla jego obcojęzycznych klientów nie ma to przecież znaczenia, ponieważ i tak nie rozumieją ani słowa po polsku ${ }^{\text {I5 }}$. Inni w zagranicznym sukcesie byłego żołnierza dopatrywali się z kolei powodów do odczuwania narodowej dumy - jakby to dopiero opinia z zewnątrz stanowiła wiarygodny wyznacznik czyjejś wielkości ${ }^{16}$.

Te oczywiste gesty akceptacji, a wręcz uznania ze strony rdzennych mieszkańców, przejawiające się choćby w zaproszeniach do udziału w lokalnych rytuałach ${ }^{\mathrm{T}}$, nie sprawiły, że artysta zapragnął dołączyć do angielskiej społeczności. Przeciwnie typograf postanowił pielęgnować w sobie przywiązanie do języka ojczystego. „Mógłbym się b[ardzo] łatwo dorobić daleko lepszej pozycji i warunków mate-

12 B. Warde, Krysztatowy kielich, czyli druk powinien być niewidoczny, tłum. D. Dziewońska, w: Widzieć / Wiedzieć. Wybór najważniejszych tekstów o dizajnie, red. P. Dębowski, J. Mrowczyk, Kraków 2011, s. 39-45. Stanisław Gliwa znał się z nią osobiście, o czym wiadomo na przykład z listu do A. Janty-Połczyńskiego, w którym typograf relacjonowal przebieg wystawy w Monotype House: „Angielski autorytet w dziedzinie typografii, Beatrice Warde, przyprowadziła nawet managera nowojorskiego Macmillana, któremu mnie przedstawiła. Żałuję, że nie mogłem tam być obecny cały czas, bo można było nawiązać sporo ciekawych kontaktów. $Z$ całej czwórki byłem jedynym, który miał książki” Biblioteka Narodowa, kolekcja A. Janty-Połczyńskiego, list S. Gliwy do A. Janty-Połczyńskiego z 29 X 1968 r., sygn. BN Rkps III 12942.

13 W 1476 r. William Caxton założył w Westminsterze pierwszy warsztat typograficzny. Wystawę dwudziestu ośmiu współczesnych private presses upamiętniającą to wydarzenie prezentowano w londyńskiej Swiss Cottage Library od 3 grudnia 1976 r. do 12 stycznia 1977 r.

14 Zob. np. R.T. Risk, Stanislaw Gliwa, Private Printer, „The Private Library” 1979, 3rd series, t. 2/1, s. 3-26; A. Ward, P. Ward, The Small Publisher. A Manual \& Case Histories, Cambridge 1979, s. $187-189$.

15 Najostrzejszą krytykę przypuścił Adam Czerniawski na łamach „Kultury” - idem, „Nieposkromione bestie stów”, „Kultura” 1967, nr 9 (239), s. 132-141.

16 Zob. np. R. Zakrzewski, Gliwy oficyna - z oknem na świat, „Orzeł Biały” 1986, nr 7/8 (1408/1409), s. $14-19$.

17 Jednym z takich wydarzeń był zorganizowany przez Oxford Guild of Printers festyn drukarzy. S. Gliwa, „Wayzgoose”, [1982?], maszynopis ze zbiorów J. Wolskiego. 
rialnych, gdybym poszedł na wydawanie tekstów angielskich, ale ani na chwilę nie żałuję, że wybrałem trudne i bardzo na obczyźnie ograniczone warunki wydawcy-drukarza polskiego" - zwierzał się Andrzejowi Kłossowskiemu ${ }^{\mathrm{I}}$. Wymownym dowodem niezgody na prostą asymilację była też rezygnacja z ubiegania się o brytyjskie obywatelstwo. Gliwa zaliczał się do emigrantów, którzy swoją narodową tożsamość osadzili w II Rzeczypospolitej, dlatego nie skorzystał z możliwości uzyskania paszportu konsularnego ani nie wyrobił sobie dokumentów brytyjskich, a jedynym dowodem tożsamości, z którego korzystał, był tak zwany travel document - dokument podróży bezpaństwowca. Permanentne wychodźstwo, nawiasem mówiąc, prowadziło czasami do nieporozumień, jak na przykład w I975 roku, gdy artysta bezskutecznie próbował zrealizować w banku czek, wystawiony mu przez debiutującą poetkę Annę Frajlich ${ }^{19}$. Po trzydziestu latach od zakończenia wojny urzędnik pracujący w kasie nie orientował się w niuansach sytuacji prawnej polskiego kombatanta na Wyspach.

Można pomyśleć, że w uporczywym trwaniu przy swoim Gliwa był oderwanym od rzeczywistości idealistą romantykiem. Byłoby to zapewne prawdą, gdyby nie silna, korespondencyjna więź z krajem, którą utrzymywał przez długie lata spędzone na emigracji. Niezłomny wśród swoich i obcych, głęboko zaangażowany w życie kulturalne polskiego Londynu, potrafił zachować realistyczny stosunek do rodaków w PRL-u, których oddzielał od oficjalnej polityki sprawowanej przez aparat państwowy. Zwykłych ludzi „stamtąd” cenił nawet wyżej od niejednego „zepsutego” rodaka na emigracji. Dostrzegał ich codzienny heroizm: „ciężko żyją i jeszcze walczyć potrafią" ${ }^{\circ}$. Tym łatwiej było mu zająć to stanowisko, że już w pierwszych latach po wojnie przeczuwał długotrwałe uzależnienie Polski od wschodniego sąsiada: „Brat mi doradza, bym jeszcze dokształcił się w muzeach brytyjskich, a potem wracał do kraju. Kształcić się oczywiście można długo, nawet do śmierci" - stwierdził gorzko w liście do Szukalskiego ${ }^{21}$.

18 Cyt. za: A. Kłossowski, Mój przyjaciel Niedźwiadek, w: Stanistaw Gliwa 1910-1986. Polski artysta książki na obczyźnie, Toruń 1987.

19 Historię tę przytoczył Jan Wolski. Zob. idem, „Droga Pani Aniu”. Debiut ksią̇̇kowy, tajniki typografii i serdeczna przyjaźn w świetle korespondencji Anny Frajlich-Zając ze Stanistawem Gliwa, w: „Tu jestem / zamieszkuje wtasne życie". Studia i szkice o twórczości Anny Frajlich, red. W. Ligęza, J. Pasterska, Kraków 2018, s. 387, przyp. 2. „Pozostanie przy polskim obywatelstwie i korzystanie - jako bezpaństwowiec $-\mathrm{z}$ «dokumentu podróży» (travel document) nieuprawniającego do odwiedzin w kraju stawało się coraz rzadsze i charakteryzowało bardziej elity polityczne, społeczne i kulturalne wychodźstwa niż szarych emigrantów, choć i takich «szeregowych niezłomnych» nie brakowało" - pisał Paweł Chojnacki (Realizm nieztomnych..., s. 112).

20 AE, kolekcja S. Szukalskiego, list S. Gliwy do S. Szukalskiego z XII 1947 r., s. 2, sygn. AE/SS/ XXXII/5.

21 AE, kolekcja S. Szukalskiego, list S. Gliwy do S. Szukalskiego z 16 II 1948 r., s. 4, sygn. AE/SS/ XXXII/5. 


\section{WYROZUMIAEY WOBEC KRAJU}

Nie wszyscy żołnierze 2. Korpusu zdecydowali się, tak jak Stanisław Gliwa, pozostać na emigracji. Ci, którzy mieli do czego lub kogo wracać, zdobyli się na ten krok. Wśród nich byli również znajomi i przyjaciele Gliwy z wojska - Tadeusz Szumański, Tadeusz Filus, Aleksander Średnicki. Artysta nie oceniał ich decyzji, uznawszy je za prywatną sprawę. W archiwum typografa w Toruniu zachowały się listy wysyłane przez nich z Polski po odwilży. Najobszerniejszy zbiór, liczący osiemdziesiąt jednostek, tworzą listy Szumańskiego, pisane w latach 1946-1985, nieco mniej jest wiadomości od Filusa - pięćdziesiąt siedem, z lat I963-I986. Najmniej napisał Średnicki - zaledwie sześć listów w latach 1975-1980. Treść tej nierzadko bardzo osobistej korespondencji ma charakter przede wszystkim wspomnieniowy. Mężczyźni przywoływali minione czasy, wspólnie spędzone w kwaterach i na polach bitewnych, opowiadali o swoich dalszych losach i nowych przedsięwzięciach, dzielili się wiedzą o znajomych w kraju oraz kibicowali Gliwie w jego pracach drukarskich. Wydaje się, że rola tych listów była dla obu stron w dużej mierze terapeutyczna. Wspólnota doświadczeń gwarantowała wzajemne zrozumienie, którego bohaterowie nie mogli znaleźć w swoich środowiskach. Jednak poza duchowym wsparciem korespondencja $\mathrm{z}$ wojskowymi kompanami przynosiła też niekiedy praktyczne korzyści. Tadeusz Filus podsunął, poznanej w Szczecinie Annie Frajlich-Zając, pomysł na wydanie debiutanckiego tomiku właśnie w oficynie Gliwy, a tym samym przyczynił się do nawiązania serdecznej, międzypokoleniowej znajomości Gliwów i Zająców ${ }^{22}$. Szumański z kolei najprawdopodobniej jako pierwszy dostarczył rodzinie Gliwy w kraju informacji o jego losach. Wypływając w 1947 roku z brytyjskiego portu, miał ze sobą komplet fotografii oraz druków korpusowych wykonanych przez grafika, które zamierzał przekazać jego matce i rodzeństwu²3.

Kontakty listowne z krajanami, zerwane na prawie dekadę stalinizmu, ożyły dopiero po 1956 roku. Wtedy to do powrotu do kraju na stałe przymierzał się Melchior Wańkowicz, a władze PRL-u zamierzały opublikować skróconą wersje Bitwy o Monte Cassino. W tej sprawie z Gliwą po dziesięcioletniej przerwie skontaktował się właśnie Szumański , który jako były fotograf 2. Korpusu miał zostać konsultantem nowego wydawnictwa. Dziad - takim pseudonimem posługiwał się przyjaciel grafika - zabiegał o pozyskanie jak najbardziej różnorodnego materiału graficznego, w którym znalazłyby się także rysunki i linoryty Gliwy. Zapytany przez grafika o to, co się z nim działo przez te wszystkie lata milczenia, napisał:

22 Tomik poezji Aby wiatr namalować ukazał się w 1976 roku.

23 Wojewódzka Biblioteka Publiczna w Toruniu (dalej: WBP), archiwum S. Gliwy, list T. Szumańskiego do S. Gliwy z 31 VII 1947 r., sygn. Rps KM 471. 
\Chcesz wiedzieć, co się ze mną działo - otóż niewiarygodnie mało. Po powrocie zastanawiałem się przez parę miesięcy, czy pracować w fotoreporterce, czy też wrócić do swego dawnego fachu, do stalownictwa. Zorientowawszy się, że jako andersowiec nie mam kwalifikacji na fotoreportera - poszedłem do biura. I tak od dziesięciu lat jestem wzorowym biurokratą na średnim stanowisku, gdyż pamiętając, żem wrócił z zagranicy, nie piąłem się wysoko. Jako fotoreporter bardzo dużo bym zarobił [...]. Ale przy panującej do niedawna szpiegomanii dla andersowca zawód niedostępny.

Nieco dalej Szumański zachęcał Gliwę do powrotu, choć w kontekście cytowanego przed chwilą fragmentu te zdania nie brzmiały przekonująco i mogły być poczytywane za trybut złożony na ręce PRL-owskiej cenzury:

》A teraz co do ciebie. Zastanów się, Stachu, czy warto, żebyś tak w obecnych twoich warunkach dalej wegetował. Szkoda lat spędzonych samotnie za granicą. W twoich warunkach nie możesz naprawdę dać z siebie wszystko [!], na co cię stać, i ze swej pracy nie osiągasz zapewne pełnego zadowolenia, jak również nic z niej nie masz. Do niedawna nie namawiałbym ani ciebie, ani też kogokolwiek. [...] Nie będziesz żałował, a pracy, i to takiej, jaka ci będzie odpowiadała, znajdziesz, ile chcesz. Masz świetny fach - i urządzisz się tu wkrótce doskonale ${ }^{24}$.

Kwestia powrotu do kraju na falach odwilży budziła wówczas na emigracji duże kontrowersje. Głośnym echem odbiły się wyjazdy Stanisława Cata-Mackiewicza i Melchiora Wańkowicza. Zwłaszcza ta druga ugoda z PRL-em musiała wywrzeć na Gliwie mocne wrażenie. Typograf bowiem utrzymywał ze słynnym pisarzem ożywione relacje - jemu też zawdzięczał pierwszy cywilny dach nad głową po przyjeździe do Londynu. Z biegiem lat intensywność kontaktów ze Starym (tak Wańkowicza nazywali Gliwa i Szumański) zmieniała się: raz była większa, innym razem zupełnie przygasała. Powrót słynnego reportażysty niewątpliwie pogorszył te wspólne relacje, jednak z czasem grafik złagodził swój sąd o przyjacielu, a nawet spotkał się z nim, gdy ten w ostatnich miesiącach życia przyjechał do Londynu na operację. Wańkowicz z kraju, podobnie jak Szumański, kusił Gliwę wizją przyjazdu:

》Staszku, Staszku! ... - proponowałem już i z USA, i z Polski przyjazd. Moje możliwości teraz są mniejsze, ale starczy i dla Pana, jak będzie 
trzeba. Gdyby tylko myśl powrotu była realna, mógłbym te swoje zapewnienia przybrać w realne zobowiązania. Ale jeśli - nie, to nie rozumiem, na Boga, dlaczego nie odwiedzić tej Polski. Deklaruję cały koszt przyjazdu, co Tili [Marta Erdman, córka Wańkowicza - J. H.] załatwi $[\ldots]^{25}$.

Typograf, wierny sobie, również z tej propozycji nie skorzystał. Sam, trwając w niezłomnej postawie, po śmierci Starego wielokrotnie się jednakże za nim ujmował, odsłaniając swój pragmatyczny, nieoceniający pogląd na cudze wybory oraz życie w PRL-u. W wywiadzie przeprowadzonym przez Reginę Wasiak-Taylor na pytanie o krajowe wydanie Bitwy o Monte Cassino odpowiedział:

\section{》 Dla wszystkich Polaków ta największa w literaturze batalistycznej książka była niezwykle ważna, gdyż mówiła o pierwszym zwycięstwie polskiego wojska nad Niemcami. Ja nie miałem wątpliwości, że po- winna ukazać się w kraju; nieważne, że bez pewnych fragmentów. [...] Wańkowiczowego pisarstwa nie da się, bez dużych strat językowych, tłumaczyć za granicą. Dla kogo on miał więc pisać? Decyzję powro- tu Mela do kraju rozumiałem doskonale ${ }^{26}$.}

Trzytomowy reportaż Wańkowicza miał dla losów Stanisława Gliwy niebagatelne znaczenie. To z powodu tej publikacji nie tylko został dłużej we Włoszech, a następnie zdecydował się na emigrację, lecz również zyskał popularność, jakiej nie udało mu się - zwykłemu nauczycielowi rysunku - zdobyć przed wojną. Niemal wszyscy recenzenci książki zwracali uwagę na niespotykaną dotąd syntezę tekstu i obrazu, osiągniętą dzięki bliskiej współpracy autora z grafikiem. Bitwa o Monte Cassino, z nazwiskiem Gliwy jako współtwórcy, nieoficjalnie docierała też do kraju, gdzie osiągała wysokie ceny, była rozchwytywana i zaczytywana. Za sprawą tej książki utrwaloną na zdjęciu sylwetkę typografa po raz pierwszy zobaczył na przykład bibliofil i poeta Edmund Puzdrowski. Zaintrygowany, swój pierwszy list do niego napisał w 1973 roku (gdańszczanin pisał także wcześniej, ale znał tylko nieaktualny adres). Znajomość w ten sposób zadzierzgnięta utrzymywała się do śmierci grafika. Puzdrowskiemu zaimponowała zarówno twórczość, jak i osobowość

25 WBP, archiwum S. Gliwy, list M. Wańkowicza do S. Gliwy z 3 IX 1966 r., sygn. Rps KM 471.

26 W Londynie o „Monte Cassino”, rozm. z S. Gliwą przeprowadziła R. Wasiak, „Opole. Miesięcznik Społeczno-Kulturalny" 1983, nr 2 (150), s. 13. Gliwa wziął także udział w dyskusji zorganizowanej przez Związek Pisarzy Polskich na Obczyźnie, podczas której - obok Zofii Romanowiczowej i Zdzisława Stahla - przedstawił swoje zdanie o Wańkowiczu. Zapis wystąpienia: S. Gliwa, Melchioriana, „Tydzień Polski” 1975, nr 12, s. 5. 
właściciela oficyny typograficznej, dlatego szybko stał się aktywnym propagatorem Gliwy w środowisku krajowych przyjaciół książki. To z jego inicjatywy artysta otrzymał na siedemdziesiąte piąte urodziny specjalny medal, upamiętniający czterech wybitnych drukarzy na obczyźnie: Stanislausa Polonusa, Samuela Tyszkiewicza, Anatola Girsa i rzecz jasna samego jubilata ${ }^{27}$.

Polscy bibliofile, między innymi pod wpływem wystąpienia Puzdrowskiego, zasypywali Gliwę listami. Głównym, choć niejedynym motywem tej korespondencji była pasja kolekcjonerska. Każdy z piszących pragnął mieć „gliwiana” w swoim księgozbiorze. Wielu z nich chciało też jednak po prostu poznać oryginalnego drukarza z Londynu, ponieważ prywatna działalność, którą prowadził, była nie do pomyślenia w kraju ze scentralizowanym, upaństwowionym rynkiem wydawniczym. Wśród listownych rozmówców znaleźli się między innymi: Andrzej Banach - historyk sztuki i kolekcjoner, graficy Zbigniew Dolatowski i Jerzy Drużycki, Janusz Dunin - księgoznawca i bibliofil, Zygfryd Gardzielewski - toruński grafik i typo$\operatorname{graf}^{28}$, Jerzy Golski - właściciel bibliofilskiego wydawnictwa Biblioteka Anińska, Helena Karpińska - introligatorka z Cieszyna, Jan Kuglin - drukarz i bibliofil, Tadeusz Przypkowski - bibliofil i konstruktor zegarów, Konstanty Maria Sopoćko drzeworytnik oraz Antoni Trepiński - bibliofil i znawca twórczości Kraszewskiego. Wszyscy wymienieni listowny kontakt z Gliwą nawiązali dopiero w latach sześćdziesiątych, po publikacji książki o Tyszkiewiczu. Tu warto dodać, że prace wydrukowane w londyńskiej oficynie, ku radości bibliofilów, docierały do kraju - zapewne dlatego, że w większości nie zawierały kontrowersyjnych treści i nie były napisane przez autorów wyraźnie zakazanych.

Typograf także czerpał korzyści z tych kontaktów. Dzięki nim dość dobrze orientował się w sytuacji w kraju. Znał nowości wydawnicze, docierały do niego wycinki z prasy oraz informacje o wydarzeniach kulturalnych, miał pojęcie o ruchu bibliofilskim, jak również warunkach publikowania książek. Drukując po polsku, regularnie doświadczał w Wielkiej Brytanii trudności ze zdobyciem materiału zecerskiego - polskie znaki diakrytyczne były jego zmorą i uniemożliwiały mu swobodny zakup krojów pism w brytyjskich odlewniach lub na rynku wtórnym. W rozmowach z krajanami dopytywał o możliwość pozyskania polskich czcionek (Bronisław Szczepski, właściciel przedsiębiorstwa dystrybuującego maszyny poligraficzne, sugerował mu na przykład skorzystanie z usług Varimexu - Polskiego Towarzystwa Handlu Zagranicznego), interesowały go także papiery z krajowych

27 J. Huppenthal, Pamięci Marii i Stanistawa Gliwórw. Zastużonych dla rozwoju i popularyzacji kultury polskiej na obczyźnie, Toruń 2010, s. 18-19.

28 Ukazała się edycja korespondencji dwóch zaprzyjaźnionych typografów: Między Toruniem a Londynem. Korespondencja Stanistawa Gliwy z Janina i Zygfrydem Gardzielewskimi, oprac. Z. Jędrzyński, Torun 2006. 
papierni, między innymi z Jeziorny i Dusznik-Zdroju. O ile jednak wiadomo, do żadnej większej transakcji nie doszło, choć niektórzy bibliofile byli gotowi posyłać mu po kilka, kilkanaście arkuszy papieru, przeważnie o dużej wartości materialnej, estetycznej lub historycznej, albo też pośredniczyć - jak Tadeusz Przypkowski w staraniach o zakup.

Większość wspólnie snutych wizji nie doczekała się realizacji. Część korespondentów - jak na przykład Antoni Trepiński ze swoją broszurą poświęconą Kraszewskiemu - miała ambicje wydawnicze, inni, jak Przypkowski, chcieli organizować Gliwie wystawy w kraju. Typograf, co można wywnioskować z treści kolejnych listów, nie zawsze odmawiał od razu - tak jakby nie chciał być nieuprzejmy lub do końca nie mógł zdecydować, czy przyjechać, czy nie. Przepaść oddzielająca go od kraju okazywała się zresztą jak najbardziej do pokonania. Dowodem na to może być niewielka książeczka $\mathrm{z}$ fragmentami poematu Komuna Paryska Władysława Broniewskiego. Drukarz wydał ją w 1975 roku wspólnie z Konstantym Marią Sopoćką - drzeworytnikiem, uczniem Władysława Skoczylasa. Siedem lat starszy od Gliwy Sopoćko, co warto podkreślić, przed wojną był członkiem warszawskiej grupy artystów drzeworytników „Ryt”, którą Gliwa wówczas ukradkiem podziwiał. Dopiero po czterdziestu latach dwaj mężczyźni nawiązali równorzędną, korespondencyjną współpracę, chociaż możliwość wydrukowania prac graficznych Sopoćki (w Komunie Paryskiej ukazało się ich dwanaście) była dla Gliwy z pewnością spełnieniem młodzieńczych marzeń.

Symboliczny powrót do młodości zapewnili typografowi również dawni członkowie Szczepu Szukalszczyków herbu Rogate Serce. Grupa początkujących artystów plastyków z Krakowa, uformowana w dwudziestoleciu międzywojennym wokół kontrowersyjnego mistrza Stanisława Szukalskiego, rozpadła się jeszcze przed wojną. Gliwa należał do tej formacji jako Kurhanin ze Słociny, przy czym nie był jej najaktywniejszym ani najzdolniejszym członkiem. Po latach Szukalski wciąż utrzymywał listowny kontakt nie tylko z Kurhaninem, lecz również z mieszkającym w kraju Marzynem z Krzeszowic (Marianem Konarskim). W archiwum typografa można znaleźć listy od Stacha $z$ Warty wysyłane do trzech adresatów: Gliwy, Konarskiego i Romana Romanowicza (siostrzeńca Szukalskiego). To Konarski po latach starań na wiosnę 1978 roku zorganizował w Krakowie i Rzeszowie wystawę retrospektywną szukalszczyków. Gliwa przesłał na nią fragment swojego graficznego dorobku: pięćdziesiąt linorytów (głównie ilustracji do książek), a także fotografie rysunków wykonanych w obozach jenieckich i jeden przedwojenny drzeworyt ${ }^{29}$.

Po przejściu na emeryturę Stanisław Gliwa coraz częściej spoglądał w stronę kraju. Wystawa czy wspólny druk to tylko dwa przykłady otwierania się na krajo- 
wego odbiorcę. Na oczach artysty w oderwaniu od żywego organizmu - Polski stopniowo i po cichu wymierała generacja ludzi o podobnych jak on poglądach politycznych. Nic dziwnego, że drukarz, widząc to, zabiegał o utrzymanie kontaktu z macierzą, w której łatwiej było mu odnaleźć zrozumienie dla swojej bibliofilskiej pasji. W ostatnich latach jego życia z pomocą przyszło mu też środowisko akademickie. Nieznane osiągnięcia polskiej prywatnej oficyny działającej na obrzeżach Londynu zaczął w kraju popularyzować księgoznawca Andrzej Kłossowski. Drukarz, zawsze chętnie dzielący się wiedzą o sobie, przesłał badaczowi bogate zestawienie wycinków z prasy emigracyjnej na swój temat - właściwie gotowy materiał do studiów. Jeszcze przed śmiercią Niedźwiadka - tak nazywali Gliwę przyjaciele - ukazała się praca Na obczyźnie. Ludzie polskiej ksią̇̇ki (1984). Jeden z jej końcowych rozdziałów $\mathrm{z}$ inspiracji Gliwy jest poświęcony właścicielom polskich oficyn typu private press. Dużo miejsca w porównaniu z innymi bohaterami zajęło w nim omówienie właśnie jego działalności.

Poza Kłossowskim życiorys typografa badała magistrantka z Uniwersytetu Wrocławskiego Anna Lipiec, której także udało się nawiązać listowny kontakt z Londynem. Dla Stanisława Gliwy, zgodnie uznawanego przez jemu współczesnych za osobę nad wyraz skromną, zainteresowanie najmłodszych badaczy było źródłem dużej satysfakcji - tym chętniej odpowiadał na zapytania wysyłane przez Lipiec, a później wysoko cenił jej rozprawę $e^{30}$.

Część wymienionych tu krajowych korespondentów typografa miała okazję przynajmniej raz spotkać go osobiście w jego domu-pracowni. Gliwa, nie mogąc, a później nie chcąc odwiedzić ojczyzny, w zamian za to od lat siedemdziesiątych gościł u siebie wielu przyjezdnych z kraju. Świadectwem tych wizyt były wspólnie złożone i odbite druczki pamiątkowe - keepsakes. Dziś dokumentują one serdeczne spotkania między innymi z małżeństwem Puzdrowskich, Tadeuszem Szumańskim, Konstantym Marią Sopoćką, Romanem Tomaszewskim, Stefanem Kubowem, Przypkowskimi czy księdzem Janem Twardowskim ${ }^{3 \mathrm{I}}$.

\section{DRUKARZ WĘDROWNY}

Sukcesy na rynku angielskim, uznanie wśród emigrantów oraz bogactwo opisanych kontaktów Gliwy z Polską dowodzą, że artysta - by użyć słów klasycznego eseju

30 A. Lipiec, „Stanisław Gliwa, polski artysta-drukarz na obczyźnie”, Wrocław 1980 - maszynopis w kolekcji A. Kłossowskiego (AE).

31 W zbiorach Muzeum Narodowego we Wrocławiu. Zob. W. Kaczorowski, Edytorskie oblicza bibliofilstwa. Broszury, druki ulotne, akcydensy. Katalog zbiorów, Wrocław 2021, passim. 
Józefa Wittlina - potrafił na własnych warunkach przezwyciężyć nieszczęście, jakim była dla niego emigracja polityczna, a ponadto znaleźć w niej pewne blaski ${ }^{32}$. Dobrą stroną jego sytuacji - od razu dostrzeganą przez rodaków - była możliwość uprawiania wolnej, nieskrępowanej przez aparat państwowy pracy drukarskiej. Nic dziwnego, że bohater w tej działalności upatrywał sensu swojego trwania na emigracji, a nawet... sensu życia. Słowo drukowane zapewniało mu nie tylko utrzymanie, lecz także możliwość realizacji własnych wizji artystycznych, szczególną estymę i łączność z macierzą.

\section{\Patrzę tu na moich przyjaciół - emerytów, jak się męczą, nagle po- zbawieni stałego zajęcia. Niektórzy w miarę możności poświęcają się pracy społecznej, inni po prostu spędzają czas na spekulacjach, ile czasu im jeszcze pozostało [...]. Jakże inaczej i korzystniej przedsta- wia się ten problem emeryta w swoim własnym kraju}

- pisał do kuzyna Stefana Kłapy, ogarnięty świątecznymi „gorzkimi rozmyślaniami”, po czym dodawał: „Mnie na szczęście ten problem nie grozi. Mogę pracować, dopóki starczy sił i energii, i nikt mi tej pracy nie odbierze"33.

Dramatyczny bieg historii, który sprawił, że typografowi przypadło w udziale życie na walizkach, był też oczywiście przedmiotem jego refleksji. Gliwa, chcąc oswoić swoją nietypową sytuację, jakoś ją zracjonalizować, zwrócił się do czasów dawno minionych. Tam ze swoimi życiorysami czekali na niego Kasper Straube i Stanislaus Polonus. Straube, pierwszy drukarz na ziemiach polskich, z pochodzenia Bawarczyk, był wędrowcem, jakich wielu w początkach epoki nowożytnej. Swój warsztat przewiózł w miejsce, gdzie jeszcze nie dotarła konkurencja - do Krakowa. Stanislaus Polonus, być może jego uczeń, najpierw drukował we Włoszech, później w Hiszpanii na dworze Izabeli Kastylijskiej ${ }^{34}$. Obaj byli drukarzami wędrownymi, wagabundami niosącymi rewolucyjną nowinkę techniczną, która zmieniła obraz ówczesnej Europy. Gliwa co prawda niczego nie rewolucjonizował, przeciwnie sięgał do rzemiosła wypartego przez maszyny, jednak podobnie jak jego odlegli poprzednicy pośredniczył w szerzeniu idei tam, gdzie było to utrudnione. Nie bez powodu swój, jak to określił, „cygański żywot” opisał w szkicu zatytułowanym $O$ wtasnej oficynie wędrownej 35 .

32 J. Wittlin, Blaski i nędze wygnania, w: idem, Orfeusz w piekle XX wieku, posł. J. Zieliński, Kraków 2000, s. 157.

33 List S. Gliwy do S. Kłapy z 26 XII 1978 r. - archiwum prywatne rodziny Kłapów.

34 A. Kawecka-Gryczowa, Przedmowa do wydania polskiego, w: A. Ruppel, Stanislaus Polonus. Polski drukarz $i$ wydawca wczesnej doby w Hiszpanii, tłum. i oprac. T. Zapiór, s. 10-11.

35 Tekst wraz z toruńskim towarzystwem bibliofilów opublikował w 1989 r. Andrzej Kłossowski. 
W ikonografii z przełomu XVII i XVIII wieku zachowało się satyryczne przedstawienie typografa „ubranego" w kasztę i prasę do odbijania czcionek. Ten oryginalny miedzioryt, pochodzący z pracy Les costumes grotesques et les métiers Nicolasa II de Larmessina, w której autor zebrał kilkadziesiąt wyobrażeń różnych zawodów, z czasem zaczął funkcjonować osobno, poza oryginalnym kontekstem, jako przedstawienie drukarza wędrownego. Stanisław Gliwa skwapliwie podjął ten motyw. W linoleum, ulubionym medium, wyciął analogiczną kompozycję, jednak modelem, który dźwigał ów nietypowy strój, uczynił samego siebie. Autotematyczna grafika, jedna $\mathrm{z}$ wielu w jego twórczości, ruszyła w świat razem z życzeniami na nowy rok, raz jeszcze przełamując wszelkie bariery geograficzne i polityczne - dokładnie tak, jak to zwykł czynić jej autor.

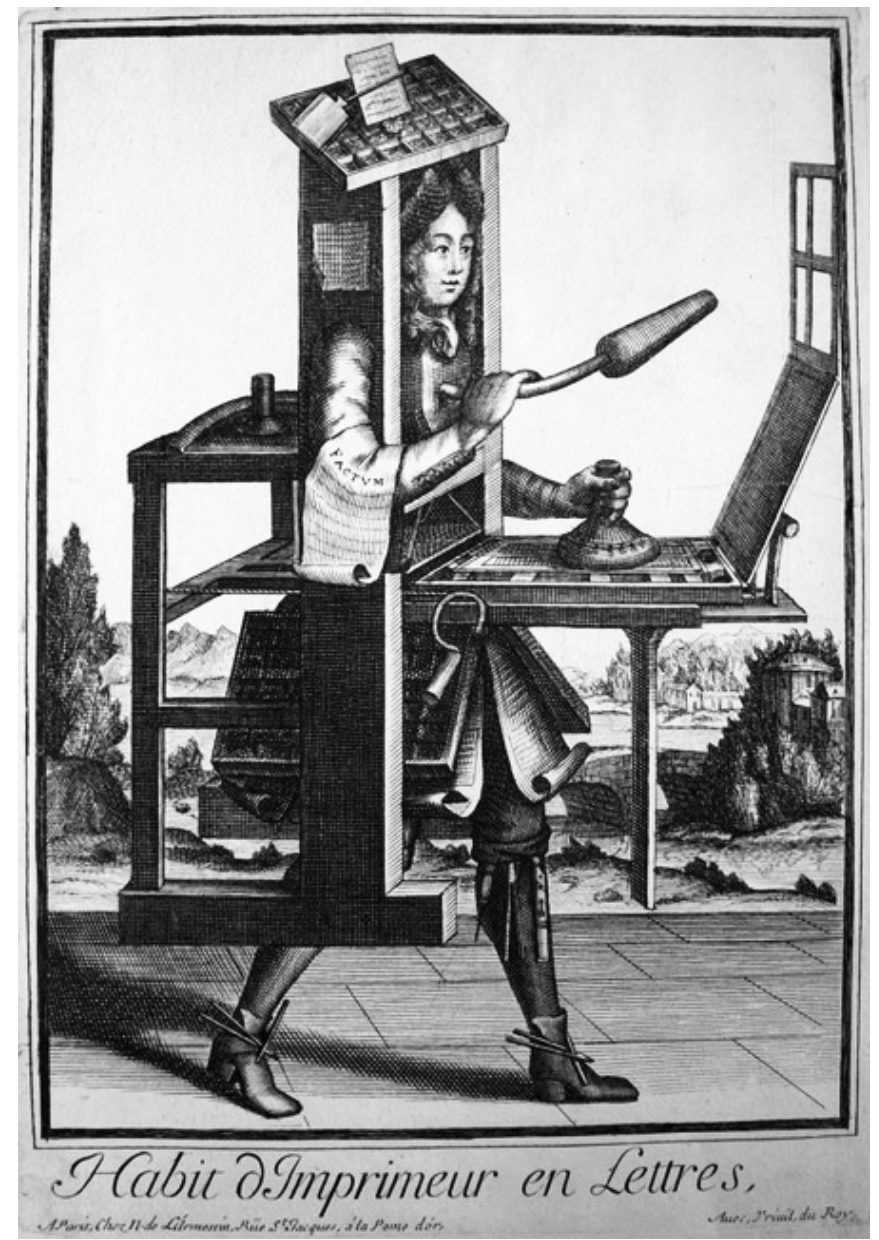

Drukarz wędrowny, a tak naprawdę osiemnastowieczny „kostium” drukarza w stylu Giuseppe Arcimbolda. Źródło: Wikimedia Commons. 


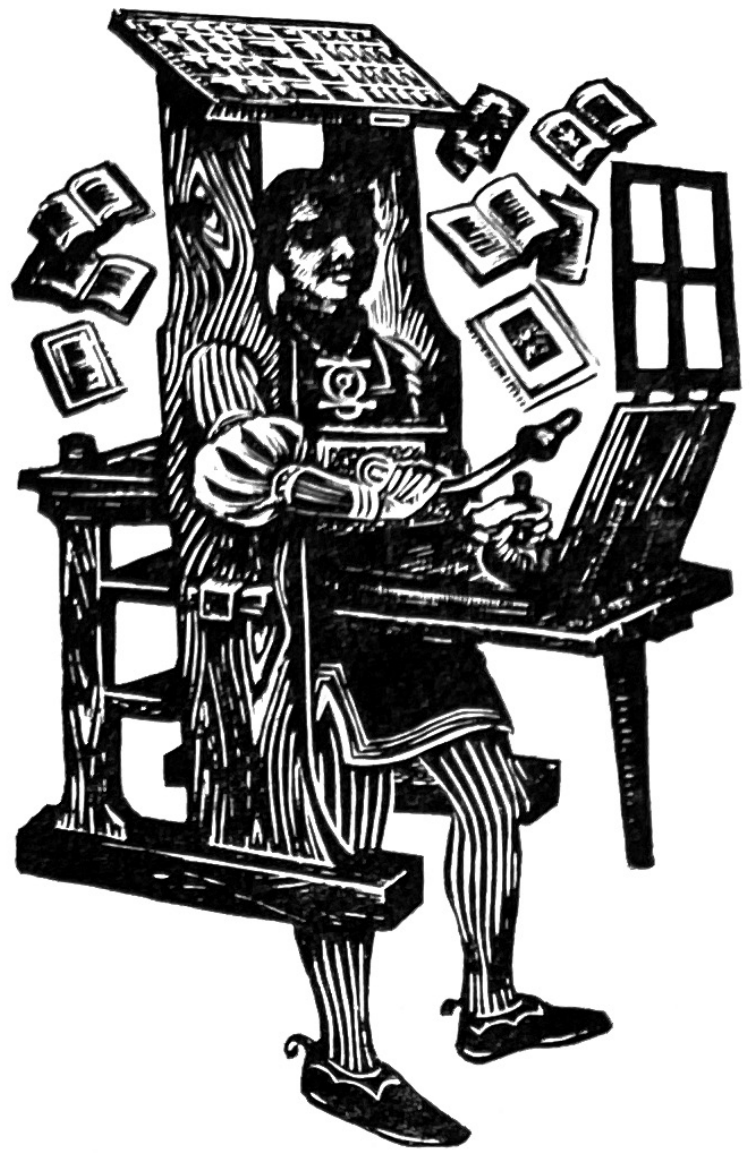

Stanisław Gliwa jako drukarz wędrowny. Linoryt odbity na karcie świąteczno-noworocznej. Źródło: Stanistaw Gliwa. Artysta grafik, drukarz i typograf wierny tradycji. 142 linoryty, oprac. J. Huppenthal, Z. Gardzielewski, Toruń 1997, s. 18.

\section{BibliografiA PODMIOTOWA}

Archiwum Emigracji w Toruniu, kolekcja S. Szukalskiego, sygn. AE/SS/XXXII/5.

Biblioteka Narodowa, kolekcja A. Janty-Połczyńskiego, sygn. BN Rkps III 12942.

List S. Gliwy do S. Kłapy z 26 XII 1978 r., archiwum prywatne rodziny Kłapów.

Wojewódzka Biblioteka Publiczna w Toruniu, archiwum S. Gliwy, sygn. Rkps KM 471.

Anders W., Bez ostatniego rozdziatu. Wspomnienia z lat 1939-1946, mapy rys. S. Gliwa, Newtown 1949.

Bohusz-Szyszko M., Rysunki, przedm. S. Zahorska, oprac. typograf. S. Gliwa, Londyn 1953.

Frajlich A., Aby wiatr namalować, oprac. typograf. S. Gliwa, Londyn 1976. 
III $\cdot$ VARIA

288

Gliwa S., Melchioriana, „Tydzień Polski”1975, nr 12.

O własnej oficynie wędrownej, oprac. A. Kłossowski, Torun 1989.

„Wayzgoose”, [1982?], maszynopis ze zbiorów J. Wolskiego.

Między Toruniem a Londynem. Korespondencja Stanistawa Gliwy z Janinq i Zygfrydem Gardzielewskimi, oprac. Z. Jędrzyński, Toruń 2006.

Przyłuski B. et al., Samuel Tyszkiewicz. Artysta-typograf, oprac. typograf. S. Gliwa, Southend-on-Sea 1962.

Przyłuski B., Strofy o malarstwie, oprac. typograf. S. Gliwa, Londyn 1953.

Wańkowicz M., Bitwa o Monte Cassino, t. 1-3, oprac. graf. S. Gliwa, L. Haar, Z. Haar, Rzym-Mediolan 1945-1947.

Zahorska S., Ofiara, rys. F. Topolski, druk S. Gliwa, Londyn 1955.

\section{BIBLIOGRAFIA PRZEDMIOTOWA}

Chojnacki P., Realizm nieztomnych. Lokalne środowiska emigracyjne wobec komunizmu i rzeczywistości krajowej od lat pięćdziesiątych po siedemdziesiąte, w: Londyn - stolica Polski. Emigracja polska 1940-1990, Warszawa 2014.

Czerniawski A., „Nieposkromione bestie stów”, „Kultura”1967, nr 9 (239).

Kaczorowski W., Edytorskie oblicza bibliofilstwa. Broszury, druki ulotne, akcydensy. Katalog zbiorów, Wroclaw 2021.

Kłossowski A., Mój przyjaciel Niedźwiadek, w: Stanistaw Gliwa 1910-1986. Polski artysta książki na obczyźnie, Toruń 1987.

Na obczyźnie. Ludzie polskiej książki, Wrocław 1984.

Kowalczyk A.S., Jerzy Giedroyc - Mieczystaw Grydzewsski: dwa style bycia emigrantem, w: Pisarz na emigracji. Mitologie, style, strategie przetrwania, red. H. Gosk, A.S. Kowalczyk, Warszawa 2005.

Lipiec A., „Stanisław Gliwa, polski artysta-drukarz na obczyźnie”, Wrocław 1980 - maszynopis w kolekcji A. Kłossowskiego, Archiwum Emigracji w Toruniu.

Risk R.T., Stanislaw Gliwa, Private Printer, „The Private Library”1979, 3rd series, t. 2/1.

Stanistaw Gliwa. Artysta grafik, drukarz i typograf wierny tradycji. 142 linoryty, oprac. J. Huppenthal, Z. Gardzielewski, Toruń 1997.

W Londynie o „Monte Cassino”, rozm. z S. Gliwą przeprowadziła R. Wasiak, „Opole. Miesięcznik Społeczno-Kulturalny"1983, nr 2 (150).

Ward A., Ward P., The Small Publisher. A Manual \& Case Histories, Cambridge 1979.

Warde B., Krysztatowy kielich, czyli druk powinien być niewidoczny, tłum. D. Dziewońska , w: Widzieć I Wiedzieć. Wybór najważniejszych tekstów o dizajnie, red. P. Dębowski, J. Mrowczyk, Kraków 2011.

Wolski J., „Droga Pani Aniu”. Debiut książkowy, tajniki typografii i serdeczna przyjaźń w świetle korespondencji Anny Frajlich-Zajac ze Stanistawem Gliwa, w: „Tu jestem / zamieszkuje wtasne życie”. Studia i szkice o twórczości Anny Frajlich, red. W. Ligęza, J. Pasterska, Kraków 2018.

Zakrzewski R., Gliwy oficyna - z oknem na świat, „Orzeł Biały” 1986, nr 7/8 (1408/1409).

SŁowa KLUCze: Stanisław Gliwa, ruch private press, książka polska za granicą, rynek wydawniczy w PRL-u, emigracja 


\section{INDOMITABLE AMONG HIS OWN AND STRANGERS, UNDERSTANDING OF the country. The attitude of StanisŁaw Gliwa as an EMigrant}

The article is dedicated to Stanisław Gliwa, a Polish owner of a private press-style publishing house, graphic designer and typographer. The author of the article analyses the attitude of Gliwa as an emigrant and one of lesser-known representatives of the so-called 'indomitable soldiers', utilising published studies and archival material available (predominantly sets of correspondence). Examining Gliwa's relationships with Poles in London, with English people, as well as with his compatriots in his home country, the author inspects how the typographer coped with isolation, which he consciously elected. In the conclusions, the author highlights the presence of the wandering printer topos, thanks to which Gliwa could universalise his experience and place it within a centuries-old cultural context.

Key words: Stanisław Gliwa, private press movement, Polish book abroad, publishing market in the Polish People's Republic, emigration 